\title{
Pengaruh Model Pembelajaran Kooperatif Tipe Talking Stick Terhadap Hasil Belajar Siswa pada Pelajaran IPA di SD Inpres 16 Kabupaten Sorong
}

\author{
Fandri Hasrudin ${ }^{1}$ \& Asrul $^{2}$
}

Program Studi PGSD, Universitas Pendidikan Muhammadiyah Sorong, Indonesia

${ }^{\bowtie}$ E-mail: fandrihasrudin@gmail.com

\begin{abstract}
Abstrak
Penelitian ini bertujuan untuk mengetahui pengaruh model pembelajaran kooperatif tipe Talking Stick Terhadap Hasil Belajar Siswa pada pelajaran IPA di SD Inpres 16 Kabupaten Sorong. Jenis penelitian yang dilakukan yaitu penelitian pra-eksperimen. Instrumen yang digunakan adalah lembar observasi guru dan siswa serta tes tertulis yang digunakan dalam penelitian ini berupa pilihan ganda sebanyak 20 soal mengacu pada hasil belajar siswa. Hasil penelitian menunjukkan bahwa hasil analisis data nilai yaitu $t_{\text {hitung }}>t_{\text {tabel }}(3,234>1,720)$, dengan besarnya taraf signifikansi 0,05 yakni $(0,04<0,05)$ maka hipotesis Ho diterima. Hasil Uji N-Gain melihat pengaruh yang diberikan model pembelajaran kooperatif tipe talking stick terhadap hasil belajar IPA siswa dari nilai rata-rata N-gain Skor yaitu 0,43 dimana nilai tersebut masuk dalam kategori sedang. Model pembelajaran kooperatif tipe talking stick berpengaruh terhadap hasil belajar IPA. Kesimpulan dari penelitian ini yaitu terdapat pengaruh yang signifikan model pembelajaran kooperatif tipe talking stick terhadap hasil belajar IPA siswa kelas V SD Inpres 16 Kabupaten Sorong pada tahun ajaran 2018/2019.
\end{abstract}

Kata Kunci: Model Pembelajaran Kooperatif; Talking Stick; Hasil Belajar Siswa.

\begin{abstract}
This study aims to determine the effect of the Talking Stick type cooperative learning model on student learning outcomes in science lessons at SD Inpres 16, Sorong Regency. This type of research is pre-experimental research. The instrument used was teacher and student observation sheets and written tests used in this study in the form of multiple choice of 20 questions referring to student learning outcomes. the results of data analysis values that are tcount>ttable (3.234>1,720), with a significance level Ie 0.05 (0.04 <0.05), the hypothesis Ho is accepted. N-Gain Test Results see the effect given by the cooperative learning model of talking stick type on students' science learning outcomes from the average value of $\mathrm{N}$-gain score is 0.43 where the value is included in the medium category. Cooperative learning model talking stick type affects the learning outcomes of science. The conclusion of this research is that there is an effect of the cooperative learning model of talking stick type on the learning outcomes of science students in class V SD Inpres 16 Sorong Regency in the $2018 / 2019$.
\end{abstract}

Keywords: Cooperative learning Model; Talking Stick; Student Learning Outcomes. 


\section{PENDAHULUAN}

Pendidikan merupakan upaya yang dilakukan secara sadar dan terencana untuk mencerdaskan dan mengembangkan potensi pesera didik melalui kegiatan bimbingan, pengajaran, atau latihan sebagai bekal di masa yang akan datang. Berdasarkan Undang-undang RI Nomor 20 Tahun 2003 pasal 3 dijelaskan bahwa pendidikan nasional berfungsi mengembangkan kemampuan dan membentuk watak serta peradaban bangsa yang bermartabat dalam rangka mencerdaskan kehidupan bangsa, bertujuan untuk berkembangnya potensi peserta didik agar menjadi manusia yang beriman dan bertakwa kepada Tuhan Yang Maha Esa, Berakhlak mulia, sehat, berilmu, cakap, kreatif, madiri, dan menjadi warga negara yang demokratis serta bertanggung jawab. Keseluruhan proses pendidikan disekolah, kegiatan belajar merupakan kegiatan yang penting, artinya berhasil tidaknya tujuan pendidikan banyak bergantung pada proses pada proses belajar yang dialami oleh peserta didik. Keberhasilan dari proses belajar ditandai dengan tercapainya tujuan pembelajaran serta hasil belajar yang optimal (Rina Murniati, 2017).

Tujuan pembelajaran dituliskan dalam beberapa pelajaran yang diajarkan Di sekolah, salah satunya adalah pelajaran IPA. Ilmu pengetahuan alam (IPA) perlu diberikan kepada semua peserta didik mulai dari sekolah dasar kerena pebelajaran IPA di SD dapat melatih keterampilan proses dan sikap ilmiah siswa, maka hendaknya dimodifikasi sesuai dengan tahap perkembangan kognitif SD. Akan tetapi pada kenyataannya banyak siswa yang kurang berminat dalam mengikuti pembelajaran IPA di dalam kelas, sehingga nilai yang diperoleh siswa tidak memenuhi kriteria (KKM) nilai yang telah ditentukan.

Hasil wawancara yang dilakukan terhadap guru wali kelas V SD Inpres 16
Kabupaten Sorong, dalam proses pembelajaran banyak siswa yang asik bermain dan kurang memperhatikan apa yang dipaparkan oleh guru. Kondisi pembelajaran tersebut mengakibatkan siswa kurang memahami materi yang disampaikan oleh guru. Siswa juga cenderung sukar diatur pada kegiatan diskusi di kelas. Guru jarang mengunakan media pembelajaran ketika mengajar, cenderung sering menggunakan metode ceramah dan ini membuat siswa merasa cepat bosan dan mengantuk. Hal itu mempengaruhi hasil belajar siswa. Berdasarkan hasil observasi awal diperoleh data yang menunjukkan bahwa Nilai IPA kelas $\mathrm{V}$ masih sangat rendah dari 22 siswa hanya 8 siswa yang nilainya tuntas dalam pelajar ini dan 14 siswa nilainya tidak tuntas.

Hasil Belajar adalah kemampuan yang diperoleh siswa melalui kegiatan belajar. Terdapat banyak faktor yang dapat menyebabkan hasil belajar siswa pada mata pembelajaran rendah, yaitu pembelajaran masih berpusat pada guru sehingga tidak melibatkan siswa secara aktif untuk berinteraksi dalam kelas dan kurangnya pengusaan guru terhadap metode-metode pembelajaran yang menyenangkan bagi siswa.

Belajar secara kooperatif adalah dimana siswa belajar bersama-sama dalam kelompok-kelompok kecil untuk memecahkan berbagai masalah dan setiap siswa tidak hanya bertanggung jawab menyelesaikan tugasnya tetapi juga menyelesaikan tugas kelompok dan membantu tugas teman kelompoknya. Model pembelajaran ini mampu melibatkan siswa secara aktif melalui proses-proses mentalnya dan meminimalkan adanya perbedaanperbedaan individu, serta meminimalisasi pengaruh negatif yang timbul dari kondisi pembelajaran kompetitif (persaingan belajar yang tidak sehat). 
Model pembelajaran kooperatif yang harus diterapkan dalam kelas adalah model pembelajaran Kooperatif Tipe Talking Stick atau yang biasa disebut tongkat berbicara. Model pembelajaran ini dilaksanakan dengan cara memberi kebebasan kepada pesera didik untuk bertanya atau guru memberi pertanyaan kepada murid tersebut. Model pembelajaran ini bertujuan agar siswa lebih percaya diri dan mampu membangkitkan semangat untuk belajar. Alasan tersebut diatas melatar belakangi tujuan peneliti ini untuk mengetahui pengaruh model pembelajaran kooperatif tipe talking stick terhadap hasil belajar siswa.

Padang sidimpuan I., 2017) bahwa Belajar menunjukan aktivitas yang dilakukan oleh seseorang yang disadari atau disengaja. Aktivitas ini menunjukan pada keaktifan seseorang dalam melakukan aspek mental yang memungkinkan terjadinya perubahan pada dirinya. Dengan demikian, juga bahwa suatu kegiatan belajar dikatakan baik apabila intensitas keaktifan jasmani maupun mental seseorang semakin tinggi.

Belajar adalah aktivitas yang dilakukan seseorang dalam keadaan sadar untuk proses perubahan tingkah laku dan perubahan pemahaman, yang pada mulanya tidak memahami kemudian dengan terjadinya proses belajar maka seorang anak berubah tingkah laku dan pemahamannya semakin bertambah.

Hasil belajar merupakan kemampuan yang diperoleh individu setelah proses belajar berlangsung, yang dapat memberikan perubahan tingkah laku baik pengetahuan, pemahaman, sikap dan keterampilan siswa sehingga menjadi lebih baik dari sebelumnya. Sebagaimana yang dikemukakan Hilgard dalam (Sulihin B. Sjukur, 2012).

Learning is process by which an activity originates or changed through training producedures (wether in laboratory or in the natural environment) as distinguished from changes by factors not atributable to training).

Menurut Hilgard dalam (Sulihin B. Sjukur, 2012) belajar itu adalah proses perubahan melalui kegiatan atau prosedur latihan baik latihan didalam laboratorium maupun dalam lingkungan alamiah. Pendapat tersebut didukung oleh sanjaya, bahwa hasil belajar adalah suatu proses aktivitas mental seseorang dalam berinteraksi dengan lingkungannya sehingga menghasilkan perubahan tingkah laku yang bersifat positif baik perubahan dalam aspek pengetahuan, sikap, maupun psikomotorik.

Hasil kajian di atas bahwa hasil belajar adalah suatu penilaian akhir dari proses dan pengenalan yang telah dilakukan berulangulang serta akan tersimpan dalam jangka waktu lama atau bahkan tidak akan hilang selama-lamanya karena hasil belajar turut serta dalam membentuk pribadi individu yang selalu ingin mencapai hasil yang lebih baik lagi sehingga akan meruba cara berpikir serta menghasilkan perilaku kerja sama yang lebih baik.

Menurut Sudjana dan Suwandi, dalam (A. Supratikna, 2012) Inti kegiatan penilaian adalah menentukan nilai dari suatu objek dengan cara membandingkan dengan kriteria tertentu. Ada tiga istilah yang merujuk pada aktivitas-aktivitas utama dalam kegiatan penilaian kelas, yaitu : (1) asesmen, (2) pengukuran, dan (evaluasi). Aktivitas pertama asesmen adalah setiap metode atau prosedur mendapatkan data sebagai dasar untuk membuat kesimpulan tentang hasil belajar murid.

Iskandar dalam (Para Mitta Purbosari, 2016) berpendapat, kata-kata "Ilmu Pengetahuan Alam" merupakan terjemahan dari kata-kata Bahasa Inggris " Natural Science" secara singkat disebut "Science". 
Natural artinya alamiah, berhubungan dengan alam atau bersangkut paut dengan alam.science artinya ilmu pengetahuan. Jadi Ilmu Pengetahuan Alam (IPA) atau science itu secara harfiah dapat disebut sebagai ilmu tentang alam ini, ilmu yang mempelajari peristiwa- peristiwa yang terjadi dialam. Pengertian lain, Menurut H.W.fowler (dalam triyanto, 2012) IPA adalah pengetahuan yang sistematis dan dirumuskan, yang berhubungan dengan gejala-gejala kebendaan dan didasarkan terutama atas pengamatan dan deduksi.

Berdasarkan uraian diatas dapat disimpulkan bahwa IPA merupakan ilmu pengetahuan yang sistemasis yang mempelajari tentang gejala-gejala alam yang lahir dan berkembang melalui metode ilmiah seperti observasi dan eksperimen dan menuntut sikap ilmiah seperti sikap jujur, dan rasa ingin tahu.

Model pembelajaran sangat penting digunakan dalam proses pembelajaran guna memberikan pengalaman dan kebermaknaan belajar siswa, hal ini akan memberikan kemudahan guru untuk mendorong siswa mencapai tujuan belajarnya. Model pembelajaran yang ada di sekolah dasar sangat beraneka ragam dan dapat dijadikan pola pilihan, artinya para guru boleh memilih model pembelajaran yang sesuai dan efisien untuk mencapai tujuan pendidikannya, penggunaan model pembelajaran yang tepat akan meningkatkan aktivitas dan hasil belajar siswa (Maulidiyah, 2014).

Hasil pendapat para ahli di atas, peneliti menyimpulkan bahwa model pembelajaran adalah pola atau rencana pembelajaran yang digunakan oleh guru sebagai pedoman dalam merencanakan dan merancang kegiatan pembelajaran yang sesuai dengan prosedur untuk mencapai tujuan pembelajaran. Model Pembelajaran membantu Guru mendesain atau merancang materi-materi pembelajaran yang sudah di susun dalam Rencana Pelaksanaan Pembelajaran agar tujuan pembelajaran tercapai secara optimal.

Model Pembelajaran Kooperatif adalah salah satu bentuk model pembelajaran yang menggunakan paham kontrukvisme. Model pembelajaran kooperatif juga membantu mendorong untuk berinteraksi secara aktif dan positif dalam kelompok. Menurut isjoni dalam (Agin Fifi Salwa, 2018) "Model pembelajaran kooperatif merupakan strategi belajar dengan sejumlah siswa sebagai anggota kelompok kecil yang tingkat kemampuannya berbeda". Johnson dan Holubec dalam (Agin Fifi Salwa, 2018), mengatakan bahwa Cooperatif Learning is a successful teaching strategy in which small teams, each with students of different levels of ability. "Artinya Pembelajaran Kooperatif adalah strategi pembelajaran yang cukup berhasil pada kelompok-kelompok kecil, di mana pada tiap kelompok tersebut terdiri dari siswa-siswi dari berbagai tingkat kemampuan, melakukan berbagai kegiatan belajar untuk meningkatkan pemahaman mereka tentang materi pelajaran yang sedang mereka pelajari (Sulistianingsih, 2014).

Hasil pendapat ahli di atas, peneliti menyimpulkan bahwa model pembelajaran kooperatif merupakan suatu pembelajaran yang melipatkan partisipasi siswa dalam satu kelompok kecil secara kolaboratif untuk saling berinteraksi. Siswa dapat menyelesaikan tugas kelompok, di harapkan setiap anggota saling bekerjasama dan membantu untuk memahami suatu materi pembelajaran.

Model Pembelajaran Kooperatif Tipe Talking Stick adalah suatu model pembelajaran kelompok dengan bantuan tongkat. Talking Stick (tongkat berbicara) merupakan tipe dari model kooperatif dari sekian banyak tipe tipe yang lain. Menurut Carol Locust Talking Stick (tongkat 
berbicara) adalah "Metode pembelajaran yang pada mulanya digunakan oleh penduduk asli Amerika untuk mengajak semua orang berbicara atau menyampaikan pendapat dalam suatu forum (pertemuan antara suku).

Definisi yang dikemukakan para ahli, maka peneliti menyimpulkan bahwa model pembelajaran kooperatif tipe talking stick merupakan model pembelajaran kelompok sambil bermain dan menyenangkan serta mendorong siswa untuk berani mengemukakan pendapat.

Kelebihan model pembelajaran kooperatif tipe talking stick dapat menjadikan peserta didik aktif dalam proses pembelajaran dan dapat mengembangkan rasa saling bekerja sama antar peserta didik serta mengembangkan kemampuan berpikir siswa. Sedangkan kekurangan model pembelajaran kooperatif tipe talking stick dapat menjadikan peserta didik senam jantung, tegang, ketakutan akan pertanyaan yang akan diberikan guru serta apabila guru tidak bisa mengendalikan kon disi kelas, maka suasana kelas akan gaduh.

Penelitian yang dilakukan $\mathrm{Ni}$ Luh $\mathrm{Kd}$ Dwi Pradnyani, I Wyn Sujana, Ni Wyn Suniasih, (2010) dengan judul "Pengaruh Penerapan Model Pembelajaran Talking Stick Terhadap Hasil Belajar IPS Siswa Kelas IV SDN 2 Sesetan Denpasar". Tujuan penelitian ini adalah untuk mengetahui perbedaan hasil belajar IPS antara siswa yang dibelajarkan melalui penerapan model pembelajaran kooperatif tipe talking stick dengan siswa yang dibelajarkan melalui pembeljaran konvensional. Hasil penelitian ini adalah nilai rata-rata kelompok eksperimen $(78,41)$ sedangkan rata-rata kelompok kontrol $(73,44)$. Ini berarti ada berbedaan yang signifikan hasil belajar IPS antara siswa yang dibelajarkan melalui penerapan model pembelajaran kooperatif tipe talking stick dengan siswa yang dibelajarkan melalui pembeljaran konvensional di SDN 2 Sesetan Denpasar.

\section{METODE PENELITIAN}

Jenis penelitian kuantitatif yang digunakan adalah pra-eksperimen. Alasannya peneliti menggunakan penelitian praeksperimen karena peneliti hanya ingin melihat pengaruh dari suatu perlakuan terhadap sampel tertentu menggunakan kelompok eksperimen saja, tanpa kelompok kontrol.

Desain yang digunakan adalah One Group Pretest Posttest. Dalam kegiatan ujicoba tidak menggunakan kelompok kontrol. Desain ini dilakukan dengan membandingkan hasil pretest dan posttest pada kelompok yang diujicobakan. Model yang digunakan dapat dilihat dari tabel 1 berikut.

Tabel 1. Desain Penelitian

\begin{tabular}{lll}
\hline O1 & $\mathrm{X}$ & $\mathrm{O} 2$ \\
\hline
\end{tabular}

Keterangan :

O1 : Pretest

$\mathrm{X}$ : Treatment atau perlakuan

O2 : Posttest

(Arikunto, 2014)

Populasi dalam penelitian ini adalah seluruh siswa SD Inpres 16 Kabupaten Sorong yang berjumlah 221 siswa. Sampel dalam penelitian ini adalah siswa kelas V SD Inpres 16 kabupaten Sorong yang berjumlah 22 siswa. Sampel adalah bagian dari jumlah dan karakteristik yang dimiliki oleh populasi. Sampel merupakan keterwakilan dari populasi, sampel harus dapat menunjukan gambaran dari populasi secara keseluruhan. Sampel tersebut diambil dari populasi, sampel menggambarkan keadaan populasi.

Teknik pengambilan sampel yang digunakan dalam penelitian ini adalah 
Purposive Sampling. Alasan menggunakan Purposive Sampling adalah karena tidak semua sampel sesuai dengan apa yang diteliti. Oleh karena itu, penulis memilih teknik Purposive Sampling yang menetapkan pertimbangan-pertimbangan atau kriteriakriteria tertentu yang harus dipenuhi oleh sampel-ampel yang digunakan dalam penelitian ini.

Teknik pengumpulan data yang digunakan dalam penelitian ini adalah Observasi. Hadi dalam (sugiyono, 2011) mengemukakan bahwa, observasi merupakan suatu yang sangat komplkes, suatu proses yang tersusun dari berbagai proses biologis dan psikologi. Teknik observasi dilakukan dengan cara pengamatan langsung tentang proses belajar dan pembelajaran di SD Inpres 16 Kabupaten Sorong.

Teknik Analisis Data pada penelitian ini yaitu uji normalitas, uji hipotesis, dan uji NGain. Uji Normalitas ini bertujuan untuk mengetahui apakah data yang terjaring dari masing-masing variabel berdistribusi normal atau tidak. Uji Normalitas ini menggunakan metode Kolmogorov-Smirnov (Uji K-S). Pengambilan keputusan dari hasil uji normalitas menggunakan metode kolmogrovsmirnov (Uji K-S) adalah jika nilai signifikansinya $>0,05$ dapat disimpulkan bahwa data berasal dari populasi yang berdistribusi normal dan jika signifikansinya $<0,05$ dapat disimpulkan bahwa data berasal dari populasi yang berdistribusi tidak normal.

\section{HASIL DAN PEMBAHASAN}

Penelitian ini menggunakan beberapa instrumen untuk pengumpulan data, yaitu instrumen observasi, tes, dan dokumentasi. Instrumen tes digunakan peneliti untuk mengetahui hasil belajar IPA siswa. Tes yang digunakan terdiri dari dua puluh soal pilihan ganda tentang udara bersih bagi kesehatan. Instrumen observasi digunakan peneliti ada dua yaitu guru dan siswa, instrumen observasi guru digunakan untuk mengetahui apakah peneliti menerapkan metode pembelajaran sesuai pada Rpp dan instrumen observasi siswa untuk mengetahui bagaimana kondisi siswa di kelas saat proses belajar mengajar. Data yang diperoleh adalah kegiatan/ aktifitas siswa serta aktifitas guru oleh observator selama proses belajar mengajar berlangsung, sebelum instrument digunakan peneliti melakukan uji validitas dan reliabilitas.

Pokok bahasan yang di ajarkan pada penelitian ini adalah udara bersih bagi kesehatan. Hasil belajar kelas tersebut dapat diukur setelah diberikan perlakuan dengan menggunakan metode pembelajaran Kooperatif Talking Stcik. Kelas tersebut diberikan tes berbentuk pilihan ganda.

Sebelum soal tersebut diberikan, terlebih dahulu dikonsultasikan dengan 1 Expert Judgement (uji ahli) dosen IPA, yaitu dosen IPA Unimuda Sorong Abdul Rachman Tiro, M.Pd. dengan cara dimintai pendapatnya tentang instrument tes yang telah disusun.

Setelah validitas dilakukan, selanjutnya adalah uji reliabilitas. Uji reliabilitas digunakan untuk mengetahui apakah butir soal yang diujikan reliabel dalam memberikan hasil pengukuran hasil belajar siswa. Untuk menguji reliabilitas instrument peneliti melakukannya melalui hasil uji coba soal pada sample yang berbeda yaitu SD Inpres 16 Kabupaten Sorong dengan sampel 20 siswa. Berdasarkan perhitungan uji reliabilitas terhadap instrumen tes menggunakan Kuder dan Richardson (K-R 20) adalah :

Tabel 2. Uji Reliabilitas K-R 20

\begin{tabular}{cc}
\hline Nilai & $\begin{array}{c}\text { Cronbach's } \\
\text { Alpha }\end{array}$ \\
\hline & 0,744 \\
\hline
\end{tabular}

Diperoleh hasil nilai reliabilitas pada tabel 
2. untuk instrument test sebesar 0,744. Berdasarkan kriteria pengujian, jika nilai reliabilitas instrument $>0,6$ maka instrument penelitian reliabel. Dengan demikan, instrument tersebut telah memenuhi syarat reliabel.

Berdasarkan hasil observasi yang menggunakan skala Guttman dengan tipe jawaban yang tegas, dari rangkaian tahapan penelitian didapatkan temuan-temuan. Hasil Observasi Aktifitas guru dan siswa dalam pembelajaran dengan menggunakan model pembelajaran kooperatif tipe talking stick yang di observasi oleh guru kelas.

Data Hasil Pretest dan Posttest Pada Kelas Eksperimen menunjukkan bahwa banyaknya kelas ada 5 dengan panjang tiap interval kelas adalah 10. Nilai yang paling banyak diperoleh siswa terletak pada interval 30 - 40 yaitu sebesar 55\% (12 orang dari 22 siswa). Sedangkan nilai yang paling sedikit diperoleh terletak pada interval $41-51$ dan $74-84$ yaitu sebesar 4\% (1 orang dari 22 siswa). Nilai rata-rata diperoleh unuk nilai pretes ini adalah 48,86. Lebih jelasnya dapat dilihat pada tabel 3 .

Tabel 3. Distribusi Hasil Belajar Pretest Siswa

Nilai

\begin{tabular}{lcl}
\hline & Absolut & Relatif \% \\
\hline $30-40$ & 12 & 55 \\
$41-51$ & 1 & 4 \\
$52-62$ & 5 & 23 \\
$63-73$ & 3 & 14 \\
$74-84$ & 1 & 4 \\
\hline Jumlah & $\mathbf{2 2}$ & $\mathbf{1 0 0} \%$
\end{tabular}

hasil uji postest menunjukkan bahwa banyaknya kelas ada 5 dengan panjang tiap interval kelas adalah 7 . Nilai yang paling banyak diperoleh siswa terletak pada interval 79 - 86 yaitu sebesar 36\% (8 orang dari 22 siswa). Sedangkan nilai yang paling sedikit diperoleh terletak pada interval 87 - 94 yaitu sebesar 4\% (1 orang dari 22 siswa). Nilai rata-rata yang diperoleh dari posttest ini adalah
72,27. Lebih jelas dapat dilihat pada tabel 4 .

Tabel 4. Distribusi Hasil Belajar Posttest Siswa

Nilai Frekuensi

\begin{tabular}{lcc}
\hline & Absolut & Relatif \% \\
\hline $55-62$ & 5 & 23 \\
$63-70$ & 5 & 23 \\
$71-78$ & 3 & 14 \\
$79-86$ & 8 & 36 \\
$87-94$ & 1 & 4 \\
\hline Jumlah & $\mathbf{2 2}$ & $\mathbf{1 0 0} \%$
\end{tabular}

Berdasarkan analisis data yang peneliti lakukan, diperoleh perhitungan dengan menggunakan SPSS versi 20 hasil belajar pretest siswa kelas $\mathrm{V}$ memiliki taraf signifikansi $0,65>0,05$ sedangkan hasil belajar postest siswa kelas $\mathrm{V}$ memiliki taraf signifikansi 0,494>0,05 sehingga ditarik kesimpulan bahwa kelas $\mathrm{V}$ sebagai kelas eksperimen berdistribusi normal. Dapat disimpulkan bahwa data dalam penelitian memiliki varian yang sama, dan data layak digunakan untuk uji selanjutnya, yaitu uji hipotesis.

Pada pengujian hipotesis pada tabel 4 dengan menggunakan uji -one sample $t$ test karena terdapat satu varian dimana data yang diuji yaitu hasil posttest dari kelas eksperimen berdasarkan hasil perhitungan maka diperoleh thitung sebesar 3,234 dengan $\mathrm{dk}=\mathrm{n}-1 \quad(22-1=21)$ diperoleh tabel sebesar 1,720. Berdasarkan hasil analisi data nilai yaitu thitung > ttabel $(3,234>1,720)$, dengan besarnya taraf signifikansi 0,05 , maka Hipotesis diterima, berarti dapat disimpulkan bahwa terdapat pengaruh pembelajaran dengan media animasi terhadap hasil belajar IPA kelas V SD Inpres 16 Kabupaten Sorong pada Tahun Ajaran 2019/2020.

Setelah melakukan uji hipotesis, dilakukan Uji N-Gain untuk mengetahui sejauh mana peningkatan skor hasil belajar siswa antara sebelum dan sesudah diterapkan model pembelajaran kooperatif tipe talking 
stick dengan mencari nilai selisih posttest dan pretest. Jadi dapat dianalisis bahwa selisih antara nilai pretes dan postes menghasilkan nilai $\mathrm{N}-$ Gain. Terdapat 1 siswa yang berada di kategori tinggi, terdapat 18 siswa yang berada di kategori sedang dan terdapat 3 siswa di kategori rendah. Sedangkan untuk rata-rata nilai pretes sebesar 48,86 dan rata rata nilai posttes sebesar 72,27 dengan perolehan rata-rata $\mathrm{N}$ gain sebesar 0,43 dan masuk dalam dalam kategori sedang.

\section{KESIMPULAN}

Berdasarkan rumusan masalah dan Berdasarkan hasil penelitian dapat diperoleh bahwa Terdapat pengaruh yang signifikan model pembelajaran kooperatif tipe talking stick terhadap hasil belajar IPA siswa kelas V SD Inpres 16 Kabupaten Sorong pada tahun ajaran 2018/2019. Dengan hasil analisis data nilai yaitu thitung > ttabel $(3,234>1,720)$, dengan besarnya taraf signifikansi 0,05 yakni $(0,04<0,05)$ maka hipotesis Ho diterima. Hasil Uji N-Gain melihat pengaruh yang diberikan model pembelajaran kooperatif tipe talking stick terhadap hasil belajar IPA siswa dari nilai rata-rata $\mathrm{N}$-gain Skor yaitu 0,43 dimana nilai tersebut masuk dalam kategori sedang. Model pembelajaran kooperatif tipe talking stick berpengaruh terhadap hasil belajar IPA.

\section{DAFTAR RUJUKAN}

A. Sumbono, (2014). Panduan SPSS Untuk Statistika Penelitian Pendidikan. Yogyakarta.

A. Supratikna, (2012). Penilaian Hasil Belajar Dengan Teknik Nontes. Halaman 2. Penerbit Universitas Sanata Dharma. Yogyakarta.

Agin Fifi Salwa, (2018). Pengaruh Model Pembelajaran Kooperatif Tipe Talking Stick Terhadap Hasil Belajar Matematika Siswa Kelas V. Halaman 12. Universitas Lampung. Diunduh 17
Mei 2019.

AP Hastuti, (2016). Hakikat Pembelajaran IPA. Halaman 5. Diunduh $15 \mathrm{Mei}$ 2019.

Arikunto, Suharsimin, (2010). Prosedur Penelitian Suatu Pendekatan Praktek Edisi (Revisi VD). Ricka Cipta. Jakarta. Halaman 203.

Asyari, Muslichah, (2006). Penerapan Sains Teknologi Masyarakat Dalam Pembelajaran Sains di SD. Depdiknas Dirjen Dikti Direktorat Ketenagaan.

Atep Sujana, 2014). Pendidikan IPA Teori dan praktik.

Depdikbud, (2009). Undang-undang Nomer 20 Tahun 2003 Tentang Sistem Pendidikan Nasional. Sinar Grafika. Jakarta

Depdiknas, (2006). Peraturan Menteri Pendidikan Nasional No 24 KTSP SD/MI.

Ellese Sulistianingsih, (2014). Tipe-tipe Model Pembelajaran Kooperatif (Coorperative Learning)

Faridhatul Khasanah, (2014). Pengaruh Penerapan Strategi Pembelajaran Aktif Tipe Teka-teki Silang Terhadap Hasil Belajar Siswa Kelas IV. Halaman 39. FKIP, Universitas Semarang. Volume 2, Page 2. Jurnal Basicude.

Fajar Ayu Astari, (2018). Efektifitas Penggunaan Model discovery Learning Dan Model Problem Based Learning Terhadap Hasil Belajar IPA

Haritsah Hammamah Harapan dan Agus Makmur Panjaitas. Penerapan Model Pembelajaran Kooperatif Tipe Talking Stick Terhadap Kemampuan Berfikir Kreatif Matematika

Heny Kusumawati (2017). Udara Bersih Bagi Kesehatan Tema 2 : Buku guru. Jakarta : Kementerian Pendidikan dan Kebudayaan

Hugo Theo Kurniason, Sugiono, Hamdan. Instrumen Tes Untuk Mengukur Kemampuan Berpikir Matematis Tingkat Tinggi SMA

Ikmila Mak'ruf, Yusuf Kendek, Kamaludin, (2009). Meningkatkan Hasil Belajar Siswa pada Mata Pelajaran IPA Kelas 
IV SDN 2 Donggulu melalui Model Pembelajaran Kooperatif. Volume 6, No.4, Halaman 165. Jurnal Kreatif Online.

Imas Kurniasih \& Berlin Sani, Ragam Pengembangan Model Pembelajaran, (Jakarta: Kata Pena, 2015), h.83.

Kadek Rai Puspitawangi, Made Citra Wibawa, Ketut Pudjawan (2016). Pengaruh Model Pembelajaran Kooperatif Tipe Talking Stick Berbantuan Media Audio Terhadap Hasil Belajar IPS Kelas IV. Volume 2 (Nomer 1, diunduh 4 april 2019

Linda Sari, (2017). Pengaruh Model Pembelajaran Kooperatif Tipe Talking Stick Terhadap Aktivitas Belajar IPA. Halaman 13-14.

Listiana, (2015). Pengertian dan Contoh Uji Data One Sample t-test serta langkahlangkah menganalisisnya menggunakan SPSS. Tuesday 01 December.http://listiana19.blogspot.co m/2015/12/uji-one-samplemenggunakan-spss.html $? m=i$

Luthfiana Tarida, (2014). Peningkatan Kemampuan Berpikir Kreatif Dan Sikap Kreatif Siswa Kelas VII Melalui Pendekatan Pendidikan Matematika Realistik Indonesia (PMRI)

Maulidiyah, (2014). Pengaruh Model Pembelajaran Kooperatif Tipe Make A Match Terhadap Hasil Belajar Siswa

Nuryani Y. Rustaman, (2004), Asesmen Pendidikan IPA. Bandung: Diklat NTT). Tersedia di htpp://www.file.upi.edu/.

Ni. Luh, K. Dwi, I. Suajana Et al, (2010).
Pengaruh Penerapan Model Pembelajaran Kooperatif Tipe Talking Stick Terhadap Hasil Belajar IPS. Diunduh 17 Mei 2019.

Padangsidimpuan I. (2017). Belajar dan Pembelajaran. Volume 03, Issue 2, Halaman 334.

Para Mitta Purbosari (2016), Pembelajaran Berbasis Proyek Membuat Ensiklopedia Ilmu Pengetahuan Alam (IPA) Untuk Meningkatkan Academic Skill. Volume 6. Page 233.

Puspasari, (2016). Model Pembelajaran Kooperatif Tipe Talking Stick Terhadap Hasil Belajar Matematika

Rina Murniati, (2017). Pengaruh Model Pembelajaran Kooperatif Tipe Talking Stick Terhadap Hasil Belajar Siswa. Halaman 6.

Rohmiati, (2013). Kemampuan Memahami Cerita Anak Melalui Metode Pembelajaran Kooperatif Tipe Talking Stick Kelas VI.

Sulihin B. Sjukur, (2012). Pengaruh Blended Learning Terhadap Motivasi Belajar dan Hasil Belajar Siswa. Volume 2, no. 3, November, 372.

Sugiyono, (2011). Metode Penelitian Kuantitatif, Kualitatif dan $R \& B$. Bandung: Alfabeta

Suprijono, Agus. 2013. Cooperative Learning: Teori dan Aplikasi Paikem. Yogyakarta: Pustaka Pelajar.

Tuti, (2015). Kemampuan Memahami Cerita Anak Melalui Metode Pembelajaran Kooperatif Tipe Talking Stick

Triyanto, (2012). Model Pembelajaran Terpadu. Jakarta: PT Bumi Aksara. 